\title{
Article \\ Phosphorus and Biofertilizer Application Effects on Growth Parameters, Yield and Chemical Constituents of Broccoli
}

\author{
Mustafa H. M. Mohamed ${ }^{1}\left(\mathbb{D}\right.$, Maha Ali $^{2}$, Rania S. M. Eid ${ }^{3}$, Heba S. El-Desouky ${ }^{3} \mathbb{D}$, Spyridon A. Petropoulos ${ }^{4, * \mathbb{D}}$, \\ Rokayya Sami ${ }^{5, *(D)}$, Amina A. M. Al-Mushhin ${ }^{6}$, Khadiga Ahmed Ismail ${ }^{7}$ (D) and Reda M. Y. Zewail ${ }^{3}$ (D)
}

1 Department of Horticulture, Faculty of Agriculture, Benha University, Moshtohor, Toukh 13736, Egypt; mustafa.muhammed@fagr.bu.edu.eg

2 Department of Soil and Water Sciences, Faculty of Agriculture, Benha University, Moshtohor, Toukh 13736, Egypt; maha.aly@fagr.bu.edu.eg

3 Department of Botany, Faculty of Agriculture, Benha University, Moshtohor, Toukh 13736, Egypt; rania.eid@fagr.bu.edu.eg (R.S.M.E.); heba.alabd@fagr.bu.edu.eg (H.S.E.-D.); reda.zewail@fagr.bu.edu.eg (R.M.Y.Z.)

4 Department of Agriculture Crop Production and Rural Environment, University of Thessaly, 38446 Nea Ionia, Greece

5 Department of Food Science and Nutrition, College of Sciences, Taif University, Taif 21944, Saudi Arabia

6 Department of Biology, College of Science and Humanities in Al-Kharj, Prince Sattam Bin Abdulaziz University, Al-Kharj 11942, Saudi Arabia; a.almushhin@psau.edu.sa

7 Department of Clinical Laboratory Sciences, College of Applied Medical Sciences, Taif University, Taif 21944, Saudi Arabia; khadigaah.aa@tu.edu.sa

Citation: Mohamed, M.H.M.; Ali, M.; Eid, R.S.M.; El-Desouky, H.S.; Petropoulos, S.A.; Sami, R.; Al-Mushhin, A.A.M.; Ismail, K.A.; Zewail, R.M.Y. Phosphorus and Biofertilizer Application Effects on Growth Parameters, Yield and Chemical Constituents of Broccoli. Agronomy 2021, 11, 2210. https:// doi.org/10.3390/agronomy11112210

Academic Editor:

Nikolaos Monokrousos

Received: 20 September 2021

Accepted: 29 October 2021

Published: 30 October 2021

Publisher's Note: MDPI stays neutral with regard to jurisdictional claims in published maps and institutional affiliations.

Copyright: (C) 2021 by the authors Licensee MDPI, Basel, Switzerland. This article is an open access article distributed under the terms and conditions of the Creative Commons Attribution (CC BY) license (https:// creativecommons.org/licenses/by/ $4.0 /)$.
* Correspondence: spetropoulos@uth.gr (S.A.P.); rokayya.d@tu.edu.sa (R.S.)

Abstract: Broccoli is a popular vegetable throughout the world and contains important nutritional features. This study was conducted to evaluate the effect the fertilization with different phosphorus sources (i.e., soil application of rock phosphate (RP) at $428 \mathrm{~kg} \mathrm{ha}^{-1}$, calcium superphosphate (CSP) at $670 \mathrm{~kg} \mathrm{ha}^{-1}$, phosphoric acid (PA) at $126 \mathrm{~L} \mathrm{ha}^{-1}$ and monoammonium phosphate (MAP) at $334 \mathrm{~kg} \mathrm{ha}^{-1}$ ) combined with biofertilizers (i.e., inoculation with phosphorin or mycorrhiza) on plant growth aspects, antioxidants enzyme activity, chemical constituents, yield and quality of broccoli leaves and heads (Brassica oleracea var. italica Plenck). The experiment was performed according to the randomized complete block design with three replications $(n=3)$, for two growing seasons (2018-2019) at the experimental farm of Benha University, Egypt. The obtained results showed that the highest values of plant height, leaf area, fresh and dry weight of leaves/plant, head weight and diameter, and the highest yield of heads $\mathrm{ha}^{-1}$ were recorded in plants that received MAP fertilizer and were inoculated with mycorrhiza. On the other hand, the highest value of head length, total carbohydrate and total soluble solids (TSS) content were observed in plants fertilized with PA and inoculated with mycorrhiza. The highest leaf nitrogen \% and head ascorbic acid content, as well as the lowest head total phenol content were recorded in plants supplemented with MAP fertilizer and inoculated with mycorrhiza. Moreover, broccoli plants fertilized with PA and inoculated with mycorrhiza showed promising results in terms of phosphorus, potassium and total carbohydrate content, antioxidant activity and dehydrogenase activity. In conclusion, phosphorus may affect plant growth, yield and chemical parameters in broccoli plants depending on the fertilizer source, while inoculation with mycorrhiza may also have a beneficial impact on these parameters.

Keywords: Brassica oleracea var. italica; phosphorus sources; total phenols; chemical composition; total carbohydrates

\section{Introduction}

Broccoli (Brassica oleracea. var italic Plenck) is widely consumed throughout the world due to its high nutritional value (e.g., a rich source of vitamins $A, B_{2}, C$, minerals [1,2], fibers and low number of calories [3]). It is also highly appreciated for its health beneficial 
properties due to its high content in antioxidants and bioactive compounds such as $\alpha$ tocopherol, $\beta$ carotene and isothiocyanates [4]. Moreover, recent evidence has confirmed its anticancer properties associated with specific phytochemicals such as organosulfuric compounds and sulforaphane and glucosinolates, in particular [5-7].

The initiation and development of broccoli inflorescence (head) is highly affected by phosphorus fertilization [8,9]. Phosphorus is considered a key nutrient in different physiological and biochemical processes [10] and its addition may also improve yield parameters [11,12]. It activates nucleic acids and phospholipids formation, induces the metabolism of carbon and also promotes enzyme activities $[13,14]$. Phosphorus is involved in vital functions of photosynthesis, respiration, energy metabolism, organic compound biosynthesis and cell division; it is also a structural element of phospholipids and nucleic acids [15]. Although P is usually applied in high amounts, plants may only absorb it in small amounts, while it could become unavailable for plants' uptake [16] due to its conversion into fixed components with soil colloidal particles in soil of either acidic or alkaline $\mathrm{pH}$ [17].

There are two forms of $\mathrm{P}$ in the soil, namely organic or inorganic [18]. Inorganic phosphorous is the form commonly absorbed by plants [19]. In order to fulfill plant requirements, high amounts of $P$ fertilizers must be applied [20], which apart from increasing cost of production, they also induce a detrimental impact on the environment and human health. Therefore, in order to reduce these negative impacts, it is important to replace inorganic $P$ fertilizers with bio-fertilizers, within the context of sustainability and the application of environment-friendly cultivation methods.

Biofertilizers, including bacteria (Bacillus megaterium) and fungi (arbuscular mycorrhizea) that may solubilize phosphates, can improve absorption of $\mathrm{P}$ by plants. The useful functions of bio-fertilizers are associated with improving soil chemical and physical properties, enhancing root surface area, maintaining soil fertility in the long term, increasing nutrient uptake, yield and quality through the increase of health beneficial phytochemicals [21-24]. Bio-fertilizers play a major role in converting fixed phosphates into $\mathrm{P}$ available for plants through the production of organic acids and the modification of soil $\mathrm{pH}[25,26]$. Microorganisms may also induce many beneficial traits, such as increased pathogen resistance and stress tolerance or higher survival rates after transplantation.

There are several reports of the effects of $P$ fertilizers and biofertilizers application on broccoli's biochemical functions and yield, however the effect of various $P$ fertilizer sources is not well examined. To determine the best source of $P$ fertilization for broccoli cultivation, this study compared rock phosphate, calcium superphosphate, phosporic acid and monoammonium phosphate combined with the application of phosphorin and mycorrhiza.

\section{Materials and Methods}

The experiment was performed for two successive growing seasons (2018 and 2019) at the experimental farm of Faculty of Agriculture, Moshtohor, Benha University, Egypt, aiming to evaluate the effect of phosphorus sources and bio-fertilizers on broccoli plants (Brassica oleracea var. italica Plenck cv. Waltham 29). The experimental area was located at an altitude of $45 \mathrm{~m}$ above mean sea level, $30.45 \mathrm{~N}$ latitude and $31.10 \mathrm{E}$ longitude. Random soil samples were collected from the experimental soil at the depth of $0-30 \mathrm{~cm}$ before planting for the analysis of the physical and chemical properties according to the protocols described in the literature $[27,28]$. Physical and chemical characters of the used soil are shown in Tables 1 and 2, respectively. Additionally, Table 3 shows the metrological data for the experimental area during 2018 and 2019 seasons. 
Table 1. Physical properties of the used soil.

\begin{tabular}{cccc}
\hline Parameters & Unit & $\mathbf{2 0 1 8 / 2 0 1 9}$ & Seasons \\
& & 5.38 & $\mathbf{2 0 1 9 / 2 0 2 0}$ \\
\hline Coarse Sand & $\%$ & 15.68 & 4.93 \\
Sand & $\%$ & 21.35 & 16.32 \\
Silt & $\%$ & 57.59 & 22.12 \\
Clay & $\%$ & Clay & 56.63 \\
Textural class & & Clay \\
\hline
\end{tabular}

Table 2. Chemical properties of the soil used.

\begin{tabular}{cccc}
\hline Parameters & Unit & \multicolumn{2}{c}{ Seasons } \\
& & $\mathbf{2 0 1 8 / 2 0 1 9}$ & $\mathbf{2 0 1 9 / 2 0 2 0}$ \\
\hline $\mathrm{CaCO}_{3}$ & $\%$ & 1.22 & 1.18 \\
Organic matter & $\%$ & 2.18 & 2.14 \\
Available nitrogen & $\mathrm{mg} \mathrm{kg}^{-1}$ & 44.35 & 42.87 \\
Available phosphorus & $\mathrm{mg} \mathrm{kg}^{-1}$ & 17.24 & 18.12 \\
Available potassium & $\mathrm{mg} \mathrm{kg}^{-1}$ & 131.9 & 128.2 \\
Electrical Conductivity (EC) & $\mathrm{dS} \cdot \mathrm{m}^{-1}$ & 1.14 & 1.17 \\
\hline
\end{tabular}

Table 3. Monthly meteorological data of the experimental site in 2018 and 2019 seasons.

\begin{tabular}{ccccccccc}
\hline \multirow{2}{*}{ Month } & \multicolumn{4}{c}{ 2018 Season } & \multicolumn{3}{c}{ 2019 Season } \\
\cline { 2 - 9 } & $\mathbf{M a x T}\left({ }^{\circ} \mathbf{C}\right)$ & MinT $\left({ }^{\circ} \mathbf{C}\right)$ & RH (\%) & DewT & MaxT $\left({ }^{\circ} \mathbf{C}\right)$ & MinT $\left({ }^{\circ} \mathbf{C}\right)$ & RH (\%) & DewT \\
\hline October & 31.44 & 19.70 & 58.64 & 15.96 & 32.57 & 20.20 & 57.72 & 16.47 \\
November & 29.71 & 17.89 & 58.20 & 14.13 & 28.57 & 15.92 & 62.30 & 12.28 \\
December & 29.71 & 12.89 & 58.20 & 14.13 & 27.13 & 11.93 & 54.51 & 7.48 \\
January & 17.67 & 9.27 & 70.03 & 7.59 & 16.20 & 8.50 & 69.23 & 7.55 \\
February & 19.61 & 9.37 & 68.58 & 8.03 & 17.23 & 8.98 & 70.22 & 7.69 \\
March & 23.12 & 10.46 & 62.35 & 8.63 & 22.15 & 9.72 & 65.13 & 8.0 \\
\hline
\end{tabular}

MaxT $=$ Maximum temperature, MinT $=$ Minimum temperature, $\mathrm{RH}(\%)=$ Relative humidity $\%$, DewT $=$ Dew point temperature.

\subsection{Plant Material and Experimental Conditions}

Seeds of broccoli (Brassica oleracea var. italica Plenck cv. Waltham 29) were obtained from Modesto Seed Company (Modesto Seed Co. Inc., Modesto, CA, USA).

Each experimental plot occupied an area of $14 \mathrm{~m}^{2}$, including five ridges of $4 \mathrm{~m}$ long and $70 \mathrm{~cm}$ in width. Broccoli seedlings were transplanted in the ridges at $30 \mathrm{~cm}$ apart on 2 October in both seasons of 2018 and 2019 when they reached the stage of 3-4 true leaves.

All plants received NK fertilizers at the recommended doses of the Egyptian Ministry of Agriculture i.e., $90 \mathrm{~kg} \mathrm{~N} \mathrm{ha}^{-1}$ as ammonium nitrate $(33 \% \mathrm{~N})$, and $96 \mathrm{~kg} \mathrm{~K} \mathrm{ha}^{-1}$ as potassium sulphate, $\left(48 \% \mathrm{~K}_{2} \mathrm{O}\right)$. All agricultural practices were performed according to the best practice guides for broccoli crops.

\subsection{Experimental Treatments}

The experimental treatments included four phosphorus sources, i.e., rock phosphate (RP), calcium superphosphate (CSP), phosphoric acid (PA) and monoammonium phosphate (MAP) applied in soil and their combination with the inoculation with phosphorin or mycorrhiza. The phosphorus fertilization treatments were as follows: (a) calcium superphosphate $\left(16 \% \mathrm{P}_{2} \mathrm{O}_{5}\right)$ at $670 \mathrm{~kg} \mathrm{ha}^{-1}$, which is equivalent to the recommended dose of mineral P $\left(108 \mathrm{~kg} \mathrm{ha}^{-1}\right)$; (b) rock phosphate $\left(25 \% \mathrm{P}_{2} \mathrm{O}_{5}\right)$ was used as a phosphatic source at $428 \mathrm{~kg} \mathrm{ha}^{-1}$, which is equivalent to the recommended dose of mineral P; (c) phosphoric acid $\left(85 \% \mathrm{P}_{2} \mathrm{O}_{5}\right)$ at $126 \mathrm{~L} \mathrm{ha}^{-1}$, which is equivalent to the recommended dose of mineral $\mathrm{P}$; (d) monoammonium phosphate $\left(54 \% \mathrm{P}_{2} \mathrm{O}_{5}\right)$ at $334 \mathrm{~kg} \mathrm{ha}^{-1}$, which is equivalent to the recommended dose of mineral $\mathrm{P}$. 
The amounts of rock phosphate and calcium superphosphate were added during soil preparation as base dressing, whereas phosphoric acid and monoammonium phosphate were divided into five equal doses and were added just before irrigation.

The used bio-fertilizers were kindly provided by the microbiology department, Faculty of Agriculture, Ain Shams University, Shoubra El-Kheima, Egypt. They contained phosphate dissolving bacteria (phosphorin), such as Bacillus megaterium or phosphate mobilizing bio-fertilizer (Arbuscular mycorrhiza; AM). The AM inoculum was made up of Glomus mosseae-NRC31 and Glomus fasciculata-NRC15, which were initially isolated from Egyptian soils; the inoculum was allowed to grow on sterilized peat-vermiculite-perlite mixtures and then was added directly by dipping the roots of broccoli seedlings for approximately 10 min before transplantation in a liquid suspension $(1 \mathrm{~L})$ containing the mycorrhiza at concentration of $10^{8} \mathrm{CFU} \mathrm{mL} \mathrm{m}^{-1}$. For phosphorin treatments, Bacillus megaterium was included and prepared by growing the bacterial strains in nutrient broth medium with continuous shaking $(140 \mathrm{rpm})$ at $30^{\circ} \mathrm{C}$ up to optimum growth. Then the cells were harvested by centrifugation $(4000 \mathrm{rpm})$ at $4^{\circ} \mathrm{C}$ for $10 \mathrm{~min}$. The cells were suspended using water peptone to prepare a suspension that contained $10^{8} \mathrm{CFU} \mathrm{mL}^{-1}$, as assessed by the optical density method, and then applied by directly dipping the roots of broccoli seedlings for approximately $10 \mathrm{~min}$ before transplantation in the liquid solution.

\subsection{Data Collection}

\subsubsection{Plant Growth Parameters}

Ten plants were sampled from each experimental plot $(n=10)$ at 60 days after transplanting to estimate the following growth parameters i.e., number of leaves, leaf area $\left(\mathrm{cm}^{2}\right.$; the 5 th true leaf from plant apex was measured by using a laser leaf area meter) and foliage of the fresh and dry weight $(\mathrm{g})$ per plant.

\subsubsection{Yield and Its Components}

At the growth stage of marketable maturity (85 days after transplanting), total yield of broccoli heads (tons per hectare), average broccoli head weight $(\mathrm{g})$, diameter $(\mathrm{cm})$ and length $(\mathrm{cm})$ were estimated in 10 plants for each replication.

\subsubsection{Chemical Constituents of Plant Foliage}

Total carbohydrate (\%), nitrogen (\%), phosphorus (\%) and potassium (\%) content of the leaves was determined in three replicates according to the methods previously described in the literature [29-32].

\subsubsection{Chemical Composition of Heads}

The following parameters were estimated in 10 broccoli heads from each plot:

a. Head total carbohydrate was determined in dry samples according to the method of Herbert et al. [29].

b. Total soluble solids (T.S.S.): A random sample of 10 heads from each experimental plot at marketable maturity stage was taken to determine the percentage of soluble solid content by using a hand refractometer (38-01 OPTi multiple scale digital handheld refractometer, Bellingham + Stanley, Xylem Analytics Germany Sales GmbH and Co. KG, WTW, Weilheim, Germany).

c. Total phenol content (mg/100 g fresh weight (F.W.)) was determined by the FolinCiocalteu protocol as described by Lu et al. [33], with minor adjustments. Polyphenols extraction was performed by adding $10 \mathrm{~mL}$ of methanol (85\%) to $1 \mathrm{~g}$ of frozen head tissues. Sterile refined water $(250 \mu \mathrm{L})$ was added to $250 \mu \mathrm{L}$ of concentrate, and afterwards $2.5 \mathrm{~mL}$ of diluted Folin-Cicalteu reagent $(10 \%)$ and $2 \mathrm{~mL}$ of $7.5 \%$ sodium carbonate were added. Samples were shaken for 1.5-2 $\mathrm{h}$ and the absorbance of samples was estimated at $765 \mathrm{~nm}$ using a spectrophotometer (Model UV752/UV754-single beam UV/Vis spectrophotometer, YK Scientific, Shanghai, China). Gallic acid was used to obtain the calibration curve and results were expressed as $\mathrm{mg} \mathrm{g}^{-1}$ [33]. 
d. Ascorbic acid was determined using the indicator of 2,6 dichlorophenol indophenol by titration as the method mentioned by the Association of Official Analytical Chemists [34]. $5 \mathrm{~g}$ of head tissues and $5 \mathrm{~mL} 1.0 \%$ of hydrochloric acid $(w / v)$ were mixed and the mixture was then subjected to centrifugation $(10,000 \times g$ for $10 \mathrm{~min})$. The supernatant liquid was collected and ascorbic acid was determined via the absorbance of the concentrate at $243 \mathrm{~nm}$ (Model UV752/UV754-single beam UV/Vis spectrophotometer, YK Scientific, Shanghai, China).

e. Antioxidant activity ( $\left.\mu \mathrm{mol} \mathrm{g}{ }^{-1} \mathrm{~F} \cdot \mathrm{W}\right)$ was determined according to Lu et al. [33]. Radical scavenging activity was tested by using the free extreme 2,2-diphenyl-2-picrylhydrazyl hydrate (DPPH) in the previously described methanol preparations (see Section 2.3.4.c). $5 \mathrm{~g}$ of ground frozen head tissues was mixed with $10 \mathrm{~mL}$ methanol and homogenized for two hours. Then, the measurement of radical scavenging activity was carried out using the DPPH solution. Briefly, $100 \mu \mathrm{L}$ of concentrate and $3.9 \mathrm{~mL}$ of a $6 \times 10^{-5} \mathrm{~mol} \mathrm{~L}^{-1}$ of DPPH solution were incubated for $30 \mathrm{~min}$. The absorbance (An) at $515 \mathrm{~nm}$ was recorded at 0 and 30 min with a spectrophotometer (Model UV752/UV754-single beam UV/Vis spectrophotometer, YK Scientific, Shanghai, China). DPPH is diminished when it responds with a cell reinforcement aggravate that changes from profound violet to light-yellow color according to Sharma et al. [17], and antioxidant activity was estimated according to the following equation:

$$
\text { Inhibition }(\%)=[(\mathrm{AB}-\mathrm{AA}) / \mathrm{AB}] \times 100
$$

where: $\mathrm{AB}=$ absorption of blank sample after $0 \mathrm{~min}$.

$\mathrm{AA}=$ absorbance of tested extract solution after $30 \mathrm{~min}$.

Radical scavenging activity (RSA) was figured as \% restrained by DPPH solutions for the indicated recipe.

f. Enzyme activity. The enzymes activity of dehydrogenase (DHA) was measured in the rhizosphere using the method of Schinner et al. [35]. Dehydrogenase activity can be measured using different tetrazolium salts, e.g., 2,3,5-triphenyl-tetrazolium chloride (TTC) as an artificial terminal hydrogen acceptor in the electron transport chain, reducing to red-colored triphenylformazan (TPF). TPF was extracted using organic solvents (e.g., methanol), and the color intensity of the extract was determined by spectroscopic methods. The intensity of the color was directly proportional to the concentration of the produced triphenylformazan.

\subsection{Statistical Analysis}

The experiment was designed according to a completely randomized block with two factors: the soil application of phosphorus and the application of bio-fertilizers. All data obtained in both seasons of the study were subjected to analysis of variance (ANOVA). The least significant difference (L.S.D.) method was used for means comparison according to Snedecor and Cocharn [36].

\section{Results}

Different data presented by ANOVA in Table 4 showed that all parameters were affected by the application of phosphorus sources (Factor A), Biofertilizers (Factor B) and their interaction $(\mathrm{A} \times \mathrm{B})$ during 2018 and 2019 seasons. Factor A recorded a highly significant effect with vegetative, yield, chemical analysis, and head quality during both seasons. For factor B, data also indicted that biofertilizer application showed signficant effect on most of the parameters during both seasons except for total phenol and ascorbic acid concentration during 2018 and 2019 seasons. For the interaction between phosphorus sources and biofertilizer application $(\mathrm{A} \times \mathrm{B})$, significant effects were observed on most of the tested parameters for both seasons during 2018 and 2019 seasons. 
Table 4. The analysis of variance (ANOVA) results for the effect of phosphorus source (Factor A), bio-fertilizers application (Factor B) and their interaction (AB) on different parameters of broccoli plants during the 2018 (1st) and 2019 (2nd) seasons.

\begin{tabular}{|c|c|c|c|c|c|c|c|c|c|}
\hline \multirow{3}{*}{$\begin{array}{l}\text { Source of } \\
\text { Variance }\end{array}$} & \multirow{3}{*}{ DF } & \multirow{2}{*}{\multicolumn{2}{|c|}{ Number of Leaves/Plant }} & \multicolumn{2}{|c|}{ Leaf Area $\left(\mathrm{cm}^{2}\right)$} & \multirow{2}{*}{\multicolumn{2}{|c|}{$\begin{array}{c}\text { Fresh Weight of } \\
\text { Leaves/Plant (g) }\end{array}$}} & \multirow{2}{*}{\multicolumn{2}{|c|}{$\begin{array}{c}\text { Dry Weight of } \\
\text { Leaves/Plant (g) }\end{array}$}} \\
\hline & & & & Mean & quare & & & & \\
\hline & & 1st & 2nd & 1st & 2nd & 1st & 2nd & 1st & 2nd \\
\hline Replicate & 2 & 2.469 & 12.304 & 184.33 & 20.083 & 1090.08 & 924.250 & 131.490 & 37.586 \\
\hline Factor A & 3 & $8.053 * *$ & $6.482 * *$ & $3373.33 * *$ & $2169.66^{* *}$ & $8707.0^{* *}$ & $242.917 * *$ & $316.545 * *$ & $272.544^{* *}$ \\
\hline Factor B & 2 & $7.949 * *$ & $7.821^{* *}$ & $1252.75 * *$ & $3049.00 * *$ & $10,396.7^{* *}$ & $8365.75^{* *}$ & $499.621^{* *}$ & $396.311^{* *}$ \\
\hline $\mathrm{AB}$ & 6 & $0.443 * *$ & $0.175 * *$ & $181.08^{* *}$ & $137.66^{* *}$ & $318.75 * *$ & $192.41^{* *}$ & $9.340^{* *}$ & $4.265 * *$ \\
\hline Error & 22 & 4.503 & 4.271 & 134.33 & 118.720 & 146.81 & 175.52 & 54.365 & 41.975 \\
\hline \multirow{3}{*}{$\begin{array}{l}\text { Source of } \\
\text { Variance }\end{array}$} & \multirow{3}{*}{ DF } & \multicolumn{2}{|c|}{ Average Head Weight (g) } & \multicolumn{2}{|c|}{ Total Yield (ton/ha) } & \multicolumn{2}{|c|}{$\begin{array}{l}\text { Average Head } \\
\text { Length }(\mathrm{cm})\end{array}$} & \multicolumn{2}{|c|}{$\begin{array}{l}\text { Average Head } \\
\text { Diameter }(\mathrm{cm})\end{array}$} \\
\hline & & \multicolumn{2}{|c|}{ Mean Square } & \multicolumn{2}{|c|}{ Mean Square } & \multicolumn{2}{|c|}{ Mean Square } & \multicolumn{2}{|c|}{ Mean Square } \\
\hline & & 1st & 2nd & 1st & 2nd & 1st & 2nd & 1st & 2nd \\
\hline Replicate & 2 & 1250.528 & 4757.58 & 0.140 & 48.565 & 0.943 & 3.326 & 10.253 & 62.230 \\
\hline Factor A & 3 & $3711.583 * *$ & $14,104.91 * *$ & $8.526^{* *}$ & $21.996 * *$ & $9.449 * *$ & $13.362 * *$ & $27.177^{* *}$ & $32.497 * *$ \\
\hline Factor B & 2 & $4535.194^{* *}$ & $10,647.00^{* *}$ & $10.494^{* *}$ & $13.519 * *$ & $28.068^{* *}$ & $34.230 * *$ & $22.327^{* *}$ & $15.707^{* *}$ \\
\hline $\mathrm{AB}$ & 6 & $319.417 * *$ & $12,977.66^{* *}$ & $0.744^{* *}$ & $0.614^{* *}$ & $0.194^{* *}$ & $0.310^{* *}$ & $0.274^{* *}$ & $0.644^{* *}$ \\
\hline Error & 22 & 436.801 & 6418.31 & 6.293 & 1.066 & 2.598 & 2.070 & 5.871 & 1.478 \\
\hline \multirow{3}{*}{$\begin{array}{l}\text { Source of } \\
\text { Variance }\end{array}$} & \multirow{3}{*}{ DF } & \multicolumn{2}{|c|}{ N\% } & \multicolumn{2}{|c|}{$\mathrm{P} \%$} & \multicolumn{2}{|c|}{ Total carbohydrates $\%$} & \multicolumn{2}{|c|}{$\mathbf{K} \%$} \\
\hline & & \multicolumn{2}{|c|}{ Mean Square } & \multicolumn{2}{|c|}{ Mean Square } & Mean & quare & Mean & quare \\
\hline & & 1st & 2nd & 1st & 2nd & 1st & 2nd & 1st & 2nd \\
\hline Replicate & 2 & 0.001 & 0.008 & 0.000 & 0.000 & 0.180 & 1.726 & 0.009 & 0.019 \\
\hline Factor A & 3 & $0.122 * *$ & $0.124^{* *}$ & $0.003^{* *}$ & $0.009 * *$ & $9.205 * *$ & $9.919 * *$ & $0.147^{* *}$ & $0.088^{* *}$ \\
\hline Factor B & 2 & $0.117^{* *}$ & $0.335 * *$ & $0.005 *$ & $0.012 * *$ & $28.27 * *$ & $21.638^{* *}$ & $0.104^{* *}$ & $0.126 * *$ \\
\hline AB & 6 & $0.003^{* *}$ & $0.005 * *$ & $0.000^{* *}$ & $0.000 * *$ & $0.180 * *$ & $0.058^{* *}$ & $0.007^{* *}$ & $0.002 * *$ \\
\hline Error & 22 & 0.021 & 0.012 & 0.000 & 0.002 & 1.041 & 1.896 & 0.004 & 0.001 \\
\hline Source of & & TSS & $\left.\operatorname{rix}{ }^{\circ}\right)$ & $\begin{array}{l}\text { Ascor } \\
(\mathrm{mg} / 1\end{array}$ & $\begin{array}{l}\text { Acid } \\
\text { g fw) }\end{array}$ & Total Car & hydrates & $\begin{array}{l}\text { Total } \\
\text { (mg/10 }\end{array}$ & $\begin{array}{l}\text { genols } \\
\text { g fw) }\end{array}$ \\
\hline Variance & DF & Mean & quare & Mean & quare & Mean & quare & Mean & quare \\
\hline & & $1 s t$ & 2nd & 1st & 2nd & 1st & 2nd & $1 s t$ & 2nd \\
\hline Replicate & 2 & 1.726 & 4.996 & 5.88 & 6.032 & 4.996 & 62.230 & 3.784 & 3.987 \\
\hline Factor A & 3 & $9.919 * *$ & $43.234 * *$ & $26.26^{* *}$ & $28.250 * *$ & $43.234^{* *}$ & $32.497 * *$ & $26.232 * *$ & $25.391 * *$ \\
\hline Factor B & 2 & $21.638^{* *}$ & $20.208^{* *}$ & 8.2700 & 7.260 & $20.208^{* *}$ & $15.707^{* *}$ & 8.159 & 8.147 \\
\hline $\mathrm{AB}$ & 6 & $0.058^{* *}$ & $0.143^{* *}$ & 0.182 & 0.187 & $0.143^{* *}$ & $0.644^{* *}$ & $0.278^{* *}$ & 0.256 \\
\hline Error & 22 & 1.896 & 2.028 & 2.03 & 2.08 & 2.028 & 1.478 & 1.589 & 1.425 \\
\hline Source of & & Antioxidar & Activity \% & $\begin{array}{r}\text { Dehyd } \\
\text { Activity ( }\end{array}$ & $\begin{array}{l}\text { PF/g dw) } \\
\text { P }\end{array}$ & & & & \\
\hline Variance & DF & Mean & quare & Mean & quare & & & & \\
\hline & & 1st & 2nd & 1st & 2nd & & & & \\
\hline Replicate & 2 & 0.012 & 0.028 & 0.135 & 0.145 & & & & \\
\hline Factor A & 3 & $0.126^{* *}$ & $0.135 * *$ & $0.089 * *$ & $0.148^{* *}$ & & & & \\
\hline Factor B & 2 & $0.338^{* *}$ & $0.235 * *$ & $0.019 * *$ & $0.109 * *$ & & & & \\
\hline $\mathrm{AB}$ & 6 & 0.012 & 0.024 & 0.089 & 0.058 & & & & \\
\hline Error & 22 & 0.029 & 0.028 & 0.039 & 0.018 & & & & \\
\hline
\end{tabular}

DF: Degrees of freedom; Factor A: phosphorus source; Factor B: bio-fertilizers application; TSS: Total soluble solids; N: Nitrogen; P: Phosphorus; K: Potassium. Comparison between the means of the treatments was performed with the Least Significant Difference (LSD) test. ${ }^{*}$ mean significant at $0.5 \% ;{ }^{* *}$ Mean significant at $1 \%$. 


\subsection{Vegetative Growth}

Data regarding the vegetative growth parameters are presented in Table 5. The results showed that monoammonium phosphate (MAP) was most effective for all the studied parameters and for both growing seasons, although no significant differences from phosphoric acid (PA) were observed for the number of leaves/plant and the fresh and dry weight of leaves/plant. On the other hand, the application of mycorrhiza showed the highest values for all the tested vegetative parameters in both seasons, except for the case of leaf area in 2018 where no significant differences from phosphorin were detected, probably due to the slight differences in meteorological conditions between the two growing seasons. Moreover, phosphorin did not result in higher vegetative growth compared to the control treatment (no inoculum) for most of the tested parameters apart from the fresh weight of leaves per plant (both seasons) and leaf area (both season). Regarding the interaction effect between bio-fertilizer and phosphorus sources treatments, data in Table 1 indicate that the combination of MAP and mycorrhiza application resulted in the highest overall values for both growing seasons, while a varied effect was observed for the rest of the treatment combinations. In contrast, the lowest values of growth parameters were recorded in the case of non-inoculated plants that received rock or superphosphate as phosphorus source.

Table 5. The effect of phosphorus source and bio-fertilizers application on vegetative growth parameters of broccoli plants during the 2018 (1st) and 2019 (2nd) seasons.

\begin{tabular}{|c|c|c|c|c|c|c|c|c|c|}
\hline \multicolumn{2}{|c|}{ Phosphorus Fertilizer Treatments } & \multicolumn{2}{|c|}{$\begin{array}{c}\text { Number of } \\
\text { Leaves/Plant }\end{array}$} & \multicolumn{2}{|c|}{$\begin{array}{l}\text { Leaf Area } \\
\qquad\left(\mathrm{cm}^{2}\right)\end{array}$} & \multicolumn{2}{|c|}{$\begin{array}{l}\text { Fresh Weight of } \\
\text { Leaves/Plant (g) }\end{array}$} & \multicolumn{2}{|c|}{$\begin{array}{l}\text { Dry Weight of } \\
\text { Leaves/Plant (g) }\end{array}$} \\
\hline Phosphorus Sources & Phosphorus Biofertlizer & $\begin{array}{c}\text { 1st } \\
\text { Season }\end{array}$ & $\begin{array}{l}\text { 2nd } \\
\text { Season }\end{array}$ & $\begin{array}{c}\text { 1st } \\
\text { Season }\end{array}$ & $\begin{array}{l}\text { 2nd } \\
\text { Season }\end{array}$ & $\begin{array}{c}\text { 1st } \\
\text { Season }\end{array}$ & $\begin{array}{l}\text { 2nd } \\
\text { Season }\end{array}$ & $\begin{array}{c}\text { 1st } \\
\text { Season }\end{array}$ & $\begin{array}{l}\text { 2nd } \\
\text { Season }\end{array}$ \\
\hline Rock phosphate (RP) & & 16.47 & 15.35 & 401 & 415 & 544 & 496 & 93.8 & 86.4 \\
\hline Superphosphate (SP) & & 17.1 & 15.37 & 410 & 415 & 559 & 504 & 97.1 & 88.0 \\
\hline Phosphoric acid (PA) & & 17.7 & 17.02 & 426 & 435 & 601 & 549 & 104.3 & 96.7 \\
\hline $\begin{array}{l}\text { Monoammonium } \\
\text { phosphate (MAP) }\end{array}$ & & 18.29 & 17.18 & 445 & 446 & 607 & 549 & 106.4 & 96.6 \\
\hline \multicolumn{2}{|c|}{ L.S.D. at $0.05^{*}$} & 0.82 & 0.91 & 11 & 10 & 11 & 12 & 6.9 & 6.3 \\
\hline \multirow{4}{*}{\multicolumn{2}{|c|}{$\begin{array}{l}\text { Phosphorın } \\
\text { Mycorrhiza }\end{array}$}} & 16.8 & 15.5 & 409 & 411 & 555 & 501 & 95.2 & 86.6 \\
\hline & & 16.96 & 16.08 & 422 & 431 & 567 & 520 & 98.3 & 91.2 \\
\hline & & 18.4 & 17.11 & 430 & 442 & 611 & 553 & 107.6 & 98.0 \\
\hline & & 0.71 & 0.79 & 9 & 9 & 10 & 11 & 6.2 & 5.4 \\
\hline \multirow{3}{*}{ Rock phosphate (RP) } & $\begin{array}{c}\text { Control } \\
\text { (no inoculum) }\end{array}$ & 15.29 & 14.51 & 389 & 406 & 512 & 473 & 87.1 & 81.3 \\
\hline & Phosphorin & 16.26 & 15.36 & 402 & 416 & 534 & 489 & 91.8 & 85.0 \\
\hline & Mycorrhiza & 17.87 & 16.19 & 413 & 425 & 587 & 528 & 102.7 & 92.9 \\
\hline \multirow{3}{*}{ Superphosphate (SP) } & $\begin{array}{c}\text { Control } \\
\text { (no inoculum) }\end{array}$ & 16.18 & 14.39 & 406 & 401 & 529 & 470 & 90.4 & 81.1 \\
\hline & Phosphorin & 17.0 & 15.22 & 416 & 412 & 551 & 505 & 95.3 & 88.3 \\
\hline & Mycorrhiza & 18.13 & 16.51 & 408 & 432 & 598 & 538 & 105.2 & 94.6 \\
\hline \multirow{3}{*}{ Phosphoric acid (PA) } & $\begin{array}{c}\text { Control } \\
\text { (no inoculum) }\end{array}$ & 17.38 & 16.68 & 418 & 416 & 584 & 537 & 100.4 & 92.9 \\
\hline & Phosphorin & 17.34 & 16.61 & 423 & 439 & 594 & 541 & 102.8 & 95.7 \\
\hline & Mycorrhiza & 18.37 & 17.78 & 437 & 451 & 627 & 571 & 109.7 & 101.6 \\
\hline \multirow{3}{*}{$\begin{array}{l}\text { Monoammonium } \\
\text { phosphate (MAP) }\end{array}$} & $\begin{array}{c}\text { Control } \\
\text { (no inoculum) }\end{array}$ & 18.37 & 16.43 & 426 & 421 & 598 & 524 & 103.1 & 91.1 \\
\hline & Phosphorin & 17.25 & 17.14 & 448 & 457 & 590 & 547 & 103.3 & 95.7 \\
\hline & Mycorrhiza & 19.24 & 17.96 & 462 & 462 & 634 & 576 & 112.8 & 103.1 \\
\hline \multicolumn{2}{|c|}{ L.S.D. at 0.05} & 1.42 & 1.58 & 19 & 18 & 2 & 22 & 12.4 & 10.9 \\
\hline
\end{tabular}

* Means comparison between treatments was performed with the least significant difference (LSD) test $(p=0.05)$. 


\subsection{Yield Parameters}

The data related to yield parameters are presented in Table 6. The application of MAP as phosphorus source resulted in the highest head weight, total yield and head diameter in both seasons, without significant differences from PA treatment. Similarly, PA application resulted in the highest head length while no significant differences from MAP were recorded. The inoculation of broccoli plants with mycorrhiza showed the most beneficial effects on all the recorded yield parameters, while no significant differences from phosphorin were recorded in the case of head length and head diameter in the 1st growing season. Moreover, the combined application of MAP or PA and mycorrhiza resulted in the highest yield parameters. In particular, MAP $\times$ mycorrhiza application increased head weight and head diameter (in both seasons) and total yield (2nd season), whereas PA $\times$ mycorrhiza treatment was the most beneficial for total yield (1st season) and head length (in both seasons). The rest of the treatments combination showed a varied effect with no specific trends being observed, although non-inoculated plants that received rock or superphosphate recorded the lowest overall values (head weight, total yield and head diameter for rock phosphate and head length for superphosphate).

Table 6. The effect of phosphorus sources and bio-fertilizers application on yield parameters of broccoli plants during the 2018 (1st) and 2019 (2nd) seasons.

\begin{tabular}{|c|c|c|c|c|c|c|c|c|c|}
\hline \multicolumn{2}{|c|}{ Phosphorus Fertilizer Treatments } & \multicolumn{2}{|c|}{$\begin{array}{l}\text { Average Head } \\
\text { Weight (g) }\end{array}$} & \multicolumn{2}{|c|}{$\begin{array}{l}\text { Total Yield } \\
\text { ton/ha }\end{array}$} & \multicolumn{2}{|c|}{$\begin{array}{l}\text { Average Head } \\
\text { Length }(\mathrm{cm})\end{array}$} & \multicolumn{2}{|c|}{$\begin{array}{l}\text { Average Head } \\
\text { Diameter }(\mathrm{cm})\end{array}$} \\
\hline Phosphorus Sources & Phosphorus Biofertlizer & $\begin{array}{c}\text { 1st } \\
\text { Season }\end{array}$ & $\begin{array}{c}\text { 2nd } \\
\text { Season }\end{array}$ & $\begin{array}{c}\text { 1st } \\
\text { Season }\end{array}$ & $\begin{array}{c}\text { 2nd } \\
\text { Season }\end{array}$ & $\begin{array}{c}\text { 1st } \\
\text { Season }\end{array}$ & $\begin{array}{c}\text { 2nd } \\
\text { Season }\end{array}$ & $\begin{array}{c}\text { 1st } \\
\text { Season }\end{array}$ & $\begin{array}{l}\text { 2nd } \\
\text { Season }\end{array}$ \\
\hline Rock phosphate (RP) & & 529 & 517 & 25.09 & 24.50 & 17.3 & 17.8 & 20.1 & 20.6 \\
\hline Superphosphate (SP) & & 534 & 529 & 25.17 & 25.18 & 16.9 & 17.6 & 20.3 & 21.0 \\
\hline Phosphoric acid (PA) & & 563 & 573 & 26.86 & 27.31 & 19.1 & 20.0 & 22.8 & 23.9 \\
\hline $\begin{array}{l}\text { Monoammonium } \\
\text { phosphate (MAP) }\end{array}$ & & 569 & 581 & 26.87 & 27.67 & 18.6 & 19.6 & 23.5 & 24.3 \\
\hline \multicolumn{2}{|c|}{ L.S.D. at $0.05^{*}$} & 20 & 14 & 1.47 & 1.0 & 1.5 & 1.4 & 2.4 & 1.2 \\
\hline & $\begin{array}{c}\text { Control } \\
\text { (no inoculum) }\end{array}$ & 530 & 521 & 24.96 & 25.07 & 16.3 & 16.9 & 20.3 & 21.5 \\
\hline & Phosphorin & 548 & 550 & 26.18 & 26.23 & 18.4 & 19.0 & 21.5 & 22.2 \\
\hline & Mycorrhiza & 569 & 571 & 26.79 & 27.19 & 19.2 & 20.3 & 23.0 & 23.7 \\
\hline \multicolumn{2}{|c|}{ L.S.D. at 0.05} & 17 & 12 & 1.28 & 0.87 & 1.3 & 1.2 & 2.0 & 1.0 \\
\hline \multirow{3}{*}{ Rock phosphate (RP) } & $\begin{array}{c}\text { Control } \\
\text { (no inoculum) }\end{array}$ & 518 & 494 & 24.33 & 23.51 & 15.8 & 16.2 & 18.6 & 19.7 \\
\hline & Phosphorin & 529 & 511 & 25.18 & 24.47 & 17.6 & 18.0 & 19.8 & 20.2 \\
\hline & Mycorrhiza & 541 & 536 & 25.75 & 25.51 & 18.7 & 19.3 & 21.7 & 22.1 \\
\hline \multirow{4}{*}{ Superphosphate (SP) } & $\begin{array}{c}\text { Control } \\
\text { (no inoculum) }\end{array}$ & 526 & 518 & 24.54 & 24.66 & 15.5 & 16.1 & 18.9 & 20.2 \\
\hline & Phosphorin & 521 & 527 & 25.13 & 25.08 & 17.2 & 17.8 & 20.1 & 20.1 \\
\hline & Mycorrhiza & 557 & 542 & 25.84 & 25.80 & 18.1 & 19.0 & 21.9 & 22.8 \\
\hline & Control (no inoculum) & 536 & 549 & 25.51 & 26.13 & 17.2 & 17.7 & 21.7 & 23.0 \\
\hline \multirow[t]{2}{*}{ Phosphoric acid (PA) } & Phosphorin & 568 & 579 & 27.04 & 27.56 & 19.8 & 20.6 & 22.6 & 23.9 \\
\hline & Mycorrhiza & 587 & 593 & 28.04 & 28.23 & 20.3 & 21.8 & 24.1 & 24.8 \\
\hline \multirow{3}{*}{$\begin{array}{l}\text { Monoammonium } \\
\text { phosphate (MAP) }\end{array}$} & Control (no inoculum) & 542 & 546 & 25.47 & 25.99 & 16.7 & 17.9 & 22.1 & 23.2 \\
\hline & Phosphorin & 575 & 584 & 27.37 & 27.80 & 19.3 & 19.7 & 23.8 & 24.5 \\
\hline & Mycorrhiza & 592 & 641 & 27.51 & 29.23 & 19.9 & 21.2 & 24.5 & 25.3 \\
\hline \multicolumn{2}{|c|}{ L.S.D. at 0.05} & 35 & 25 & 2.56 & 1.74 & 2.7 & 2.4 & 4.1 & 2.0 \\
\hline
\end{tabular}

* Means comparison between treatments was performed with the least significant difference (LSD) test $(p=0.05)$. 


\subsection{Chemical Composition of Foliage}

The results in Table 7 indicated that macronutrient and total carbohydrate content in broccoli leaves were beneficially affected by either MAP or PA application. In particular, nitrogen $(\mathrm{N})$ content $(\%)$ was the highest when plants were treated with MAP, without significant differences from the PA treatment being observed. On the other hand, phosphorus $(\mathrm{P})$ and potassium $(\mathrm{K})$ content was the highest for the PA treatment, while K content in the 1st growing season did not differ significantly between PA and MAP treatments. Finally, total carbohydrate content was beneficially affected by the application of either MAP or PA since no significant differences were observed between these treatments. Moreover, the inoculation of plants with mycorrhiza had a consistent beneficial effect on macronutrients and total carbohydrate content, being significantly different from the phosphorin and the control treatment in all the cases except for the $\mathrm{N}$ content in the 1st growing season where it did not differ from the phosphorin treatment. This finding could be partly attributed to the slight differences in meteorological conditions between the growing seasons, although no specific trends were recorded. Regarding the combined application of the tested phosphorus sources and biofertilizers, a varied effect was observed. In particular, $\mathrm{N}$ content was the highest when MAP was combined with mycorrhiza inoculation, the highest values for the rest of the tested parameter ( $\mathrm{K}, \mathrm{P}$ and total carbohydrate content) was recorded for the combination of PA and mycorrhiza inoculation. In contrast, the application of rock phosphate (RP) or superphosphate (SP) with no addition of biofertilizers resulted in the lowest overall values for $\mathrm{N}$ and $\mathrm{K}$ (only in the first season), $\mathrm{P}$ (in both seasons) and total carbohydrate content (only in the second season) in the case of RP, as well as for $\mathrm{N}$ and $\mathrm{K}$ (only in the second season) and total carbohydrate content (only in the second season) in the case of SP.

Table 7. The effect of phosphorus sources and bio-fertilizers application on the chemical composition of foliage of broccoli plants during the 2018 (1st) and 2019 (2nd) seasons.

\begin{tabular}{|c|c|c|c|c|c|c|c|c|c|}
\hline \multicolumn{2}{|c|}{ Phosphorus Fertilizer Treatments } & \multicolumn{2}{|c|}{$\mathrm{N} \%$} & \multicolumn{2}{|c|}{$\mathbf{P} \%$} & \multicolumn{2}{|c|}{$\mathbf{K} \%$} & \multicolumn{2}{|c|}{$\begin{array}{c}\text { Total } \\
\text { Carbohydrates\% }\end{array}$} \\
\hline Phosphorus Sources & Phosphorus Biofertlizer & $\begin{array}{c}\text { 1st } \\
\text { Season }\end{array}$ & $\begin{array}{l}\text { 2nd } \\
\text { Season }\end{array}$ & $\begin{array}{c}\text { 1st } \\
\text { Season }\end{array}$ & $\begin{array}{l}\text { 2nd } \\
\text { Season }\end{array}$ & $\begin{array}{c}\text { 1st } \\
\text { Season }\end{array}$ & $\begin{array}{l}\text { 2nd } \\
\text { Season }\end{array}$ & $\begin{array}{c}\text { 1st } \\
\text { Season }\end{array}$ & $\begin{array}{l}\text { 2nd } \\
\text { Season }\end{array}$ \\
\hline \multicolumn{2}{|l|}{ Rock phosphate (RP) } & 1.57 & 1.51 & 0.254 & 0.274 & 1.35 & 1.30 & 14.05 & 13.29 \\
\hline & 1.60 & 1.54 & 0.262 & 0.282 & 1.32 & 1.26 & 13.73 & 13.18 \\
\hline \multicolumn{2}{|l|}{ Phosphoric acid (PA) } & 1.78 & 1.71 & 0.292 & 0.313 & 1.57 & 1.46 & 15.57 & 15.13 \\
\hline \multicolumn{2}{|l|}{$\begin{array}{l}\text { Monoammonium } \\
\text { phosphate (MAP) }\end{array}$} & 1.79 & 1.74 & 0.280 & 0.304 & 1.54 & 1.42 & 15.58 & 14.97 \\
\hline \multicolumn{2}{|c|}{ L.S.D. at $0.05^{*}$} & 0.14 & 0.10 & 0.002 & 0.002 & 0.06 & 0.03 & 0.99 & 1.34 \\
\hline \multirow{4}{*}{\multicolumn{2}{|c|}{$\begin{array}{c}\text { (no inoculum) } \\
\text { Phosphorin } \\
\text { Mycorrhiza }\end{array}$}} & 1.59 & 1.44 & 0.250 & 0.273 & 1.36 & 1.26 & 13.25 & 12.86 \\
\hline & & 1.69 & 1.65 & 0.237 & 0.289 & 1.44 & 1.36 & 14.70 & 14.02 \\
\hline & & 1.78 & 1.77 & 0.292 & 0.317 & 1.54 & 1.46 & 16.32 & 15.54 \\
\hline & & 0.12 & 0.09 & 0.001 & 0.002 & 0.05 & 0.02 & 0.86 & 1.16 \\
\hline \multirow{3}{*}{ Rock phosphate (RP) } & $\begin{array}{c}\text { Control } \\
\text { (no inoculum) }\end{array}$ & 1.46 & 1.35 & 0.238 & 0.252 & 1.27 & 1.21 & 12.35 & 11.82 \\
\hline & Phosphorin & 1.56 & 1.51 & 0.251 & 0.276 & 1.37 & 1.29 & 14.18 & 13.19 \\
\hline & Mycorrhiza & 1.71 & 1.68 & 0.274 & 0.295 & 1.42 & 1.40 & 15.62 & 14.87 \\
\hline \multirow{3}{*}{ Superphosphate (SP) } & $\begin{array}{c}\text { Control } \\
\text { (no inoculum) }\end{array}$ & 1.51 & 1.32 & 0.241 & 0.262 & 1.29 & 1.18 & 12.14 & 11.91 \\
\hline & Phosphorin & 1.62 & 1.58 & 0.264 & 0.274 & 1.31 & 1.24 & 13.94 & 13.02 \\
\hline & Mycorrhiza & 1.68 & 1.72 & 0.281 & 0.312 & 1.38 & 1.36 & 15.12 & 14.61 \\
\hline \multirow{3}{*}{ Phosphoric acid } & $\begin{array}{c}\text { Control } \\
\text { (no inoculum) }\end{array}$ & 1.69 & 1.58 & 0.268 & 0.293 & 1.48 & 1.32 & 14.32 & 13.93 \\
\hline & Phosphorin & 1.82 & 1.73 & 0.296 & 0.308 & 1.52 & 1.49 & 15.31 & 15.05 \\
\hline & Mycorrhiza & 1.84 & 1.83 & 0.312 & 0.338 & 1.72 & 1.59 & 17.39 & 16.40 \\
\hline \multirow{3}{*}{ MAP } & $\begin{array}{c}\text { Control } \\
\text { (no inoculum) }\end{array}$ & 1.70 & 1.54 & 0.254 & 0.286 & 1.41 & 1.34 & 14.21 & 13.80 \\
\hline & Phosphorin & 1.77 & 1.81 & 0.283 & 0.301 & 1.56 & 1.42 & 15.38 & 14.83 \\
\hline & Mycorrhiza & 1.92 & 1.88 & 0.304 & 0.325 & 1.67 & 1.52 & 17.16 & 16.29 \\
\hline \multicolumn{2}{|c|}{ L.S.D. at 0.05} & 0.24 & 0.18 & 0.003 & 0.004 & 0.10 & 0.05 & 1.72 & 2.33 \\
\hline
\end{tabular}

* Means comparison between treatments was performed with the least significant difference (LSD) test $(p=0.05)$. 


\subsection{Quality Parameters of Broccoli Heads}

Quality parameters related to the chemical composition of broccoli heads are presented in Table 8. Our results showed that quality of broccoli heads is affected by phosphorus application depending on the selected phosphorus source. Therefore, total soluble solids content (TSS) was the highest when MAP or PA were applied in the first and second growing season, respectively, while ascorbic acid content was the highest when MAP was selected as the phosphorus source, regardless of the growing season. On the other hand, total carbohydrate content was beneficially affected by the application of PA, although no statistically significant differences were recorded from the treatment of MAP. Similarly, SP was the best performing treatment in terms of total phenol content, followed by the application of rock phosphate with no statistically significant differences between these two treatments. Regarding the tested biofertilizers, mycorrhiza inoculation resulted in the highest overall values for the tested parameters, except for the case of total phenols where the highest content was recorded when phosphorus was applied in the form of superphosphate, followed by the treatment of rock phosphate. The combined effect of phosphorus sources and biofertilizers showed a varied response depending on the evaluated parameter. Therefore, heads collected from plants treated with PA and mycorrhiza had the highest TSS and total carbohydrates content, while plants treated with MAP and mycorrhiza recorded the highest values of ascorbic acid content. Finally, total phenol content was recorded when plants were not inoculated with biofertilizers and the applied phosphorus source was superphosphate (second season) or rock phosphate (second season). On the other hand, the lowest overall values for most of the quality parameters tested were recorded for non-inoculated plants treated with rock (TSS and total carbohydrate content in the 1st season and ascorbic acid content in both seasons) or superphosphate (TSS and total carbohydrate content in the second season). Interestingly, the lowest total phenol content was observed in plants treated with the combination of MAP $x$ mycorrhiza treatments.

Table 8. The effect of phosphorus sources and bio-fertilizers application on quality parameters of broccoli heads during the 2018 (1st) and 2019 (2nd) seasons.

\begin{tabular}{|c|c|c|c|c|c|c|c|c|c|}
\hline \multicolumn{2}{|c|}{ Phosphorus Fertilizer Treatments } & \multicolumn{2}{|c|}{ TSS $\left(\right.$ Brix $\left.^{\circ}\right)$} & \multicolumn{2}{|c|}{$\begin{array}{l}\text { Ascorbic Acid } \\
(\mathrm{mg} / 100 \mathrm{~g} \text { fw })\end{array}$} & \multicolumn{2}{|c|}{$\begin{array}{c}\text { Total } \\
\text { Carbohydrates (\%) }\end{array}$} & \multicolumn{2}{|c|}{$\begin{array}{l}\text { Total Phenols } \\
(\mathrm{mg} / 100 \mathrm{~g} \mathrm{fw})\end{array}$} \\
\hline Phosphorus Sources & Phosphorus Biofertlizer & $\begin{array}{c}\text { 1st } \\
\text { Season }\end{array}$ & $\begin{array}{l}\text { 2nd } \\
\text { Season }\end{array}$ & $\begin{array}{c}\text { 1st } \\
\text { Season }\end{array}$ & $\begin{array}{l}\text { 2nd } \\
\text { Season }\end{array}$ & $\begin{array}{c}\text { 1st } \\
\text { Season }\end{array}$ & $\begin{array}{l}\text { 2nd } \\
\text { Season }\end{array}$ & $\begin{array}{c}\text { 1st } \\
\text { Season }\end{array}$ & $\begin{array}{l}\text { 2nd } \\
\text { Season }\end{array}$ \\
\hline Rock phosphate (RP) & & 6.16 & 6.53 & 95.8 & 93.4 & 16.21 & 15.27 & 422 & 406 \\
\hline Superphosphate (SP) & & 6.20 & 6.54 & 99.9 & 98.7 & 16.40 & 15.57 & 427 & 414 \\
\hline Phosphoric acid (PA) & & 6.29 & 7.40 & 114.2 & 107.2 & 20.34 & 18.66 & 387 & 385 \\
\hline $\begin{array}{l}\text { Monoammonium } \\
\text { phosphate (MAP) }\end{array}$ & & 7.13 & 7.31 & 121.0 & 113.7 & 19.83 & 18.31 & 366 & 374 \\
\hline \multicolumn{2}{|c|}{ L.S.D. at 0.05 * } & 0.18 & 0.11 & 4.2 & 3.4 & 1.39 & 1.03 & 10.9 & 28 \\
\hline & Control (no inoculum) & 6.01 & 6.27 & 96.6 & 94.1 & 17.05 & 15.40 & 418 & 406 \\
\hline & Phosphorin & 6.77 & 7.06 & 109.9 & 104.9 & 17.93 & 17.05 & 398 & 395 \\
\hline & Mycorrhiza & 7.31 & 7.50 & 116.6 & 110.8 & 19.6 & 18.41 & 386 & 383 \\
\hline \multicolumn{2}{|c|}{ L.S.D. at 0.05} & 0.16 & 0.10 & 3.6 & 3.0 & 1.20 & 0.89 & 9 & 24 \\
\hline \multirow{4}{*}{ Rock phosphate (RP) } & Control (no inoculum) & 5.29 & 5.67 & 86.2 & 89.5 & 14.82 & 13.96 & 438 & 426 \\
\hline & Phosphorin & 6.37 & 6.84 & 98.7 & 92.8 & 16.17 & 15.28 & 421 & 402 \\
\hline & Mycorrhiza & 6.84 & 7.08 & 102.6 & 98.1 & 17.64 & 16.58 & 408 & 391 \\
\hline & Control (no inoculum) & 5.32 & 5.62 & 91.8 & 95.8 & 15.16 & 13.80 & 451 & 423 \\
\hline \multirow[t]{3}{*}{ Superphosphate (SP) } & Phosphorin & 6.32 & 6.87 & 98.1 & 96.7 & 16.12 & 16.00 & 417 & 422 \\
\hline & Mycorrhiza & 6.97 & 7.13 & 110.0 & 103.8 & 17.92 & 16.92 & 415 & 398 \\
\hline & Control (no inoculum) & 6.82 & 6.94 & 102.4 & 92.7 & 19.29 & 16.91 & 401 & 396 \\
\hline \multirow[t]{2}{*}{ Phosphoric acid (PA) } & Phosphorin & 7.24 & 7.32 & 118.3 & 112.2 & 20.12 & 18.74 & 398 & 382 \\
\hline & Mycorrhiza & 7.83 & 7.96 & 121.8 & 116.7 & 21.60 & 20.34 & 369 & 378 \\
\hline \multirow{3}{*}{$\begin{array}{l}\text { Monoammonium } \\
\text { phosphate (MAP) }\end{array}$} & Control (no inoculum) & 6.61 & 6.85 & 106.3 & 98.6 & 18.92 & 16.95 & 382 & 380 \\
\hline & Phosphorin & 7.18 & 7.24 & 124.6 & 118.0 & 19.31 & 18.16 & 364 & 374 \\
\hline & Mycorrhiza & 7.62 & 7.85 & 132.0 & 124.5 & 21.25 & 19.82 & 352 & 368 \\
\hline \multicolumn{2}{|c|}{ L.S.D. at 0.05} & 0.32 & 0.20 & 7.2 & 6.1 & 2.41 & 1.79 & 19 & 49 \\
\hline
\end{tabular}

* Means comparison between treatments was performed with the least significant difference (LSD) test $(p=0.05)$. 


\subsection{Antioxidant and Enzymes Activity}

The results of the antioxidant and enzyme activity are presented in Table 9. The application of MAP resulted in the highest antioxidant and dehydrogenase activity for both seasons, while similar results were recorded for the plants treated with mycorrhiza. Finally, the combination of these treatments resulted in the highest overall values for antioxidant and dehydrogenase activity, regardless of the growing season. In contrast, the lowest values were observed for the combination of $\mathrm{RP} \times$ control (no inoculum) treatments.

Table 9. The effect of phosphorus sources and biofertilizer application on antioxidant and dehydrogenase activity of broccoli heads during the 2018 (1st) and 2019 (2nd) seasons.

\begin{tabular}{|c|c|c|c|c|c|}
\hline \multicolumn{2}{|c|}{ Phosphorus Pertilizer Treatments } & \multicolumn{2}{|c|}{ Antioxidant Activity \% } & \multicolumn{2}{|c|}{$\begin{array}{c}\text { Dehydrogenase Activity } \\
(\mu \mathrm{gTPF} / \mathrm{g} \mathrm{dw})\end{array}$} \\
\hline Phosphorus Sources & $\begin{array}{l}\text { Phosphorus } \\
\text { Biofertlizer }\end{array}$ & 1st Season & 2nd Season & 1st Season & 2nd Season \\
\hline Rock phosphate (RP) & & 0.58 & 0.54 & 40.9 & 37.8 \\
\hline Superphosphate (SP) & & 0.60 & 0.56 & 41.5 & 38.3 \\
\hline Phosphoric acid (PA) & & 0.68 & 0.63 & 48.2 & 43.6 \\
\hline $\begin{array}{l}\text { Monoammonium } \\
\text { phosphate (MAP) }\end{array}$ & & 0.70 & 0.66 & 50.5 & 46.7 \\
\hline \multirow[t]{4}{*}{ L.S.D. at $0.05^{*}$} & & 0.04 & 0.03 & 1.7 & 1.0 \\
\hline & $\begin{array}{l}\text { Control (no } \\
\text { inoculum) }\end{array}$ & 0.60 & 0.54 & 36.8 & 33.7 \\
\hline & Phosphorin & 0.62 & 0.60 & 44.4 & 40.5 \\
\hline & Mycorrhiza & 0.69 & 0.66 & 54.6 & 50.6 \\
\hline \multirow[t]{2}{*}{ L.S.D. at 0.05} & & 0.03 & 0.02 & 1.4 & 0.8 \\
\hline & $\begin{array}{l}\text { Control (no } \\
\text { inoculum) }\end{array}$ & 0.52 & 0.48 & 32.7 & 29.5 \\
\hline \multirow{3}{*}{ Rock phosphate (RP) } & Phosphorin & 0.59 & 0.54 & 41.8 & 38.7 \\
\hline & Mycorrhiza & 0.64 & 0.61 & 48.3 & 45.2 \\
\hline & $\begin{array}{l}\text { Control (no } \\
\text { inoculum) }\end{array}$ & 0.56 & 0.46 & 34.2 & 31.0 \\
\hline \multirow{3}{*}{ Superphosphate (SP) } & Phosphorin & 0.57 & 0.58 & 40.3 & 38.0 \\
\hline & Mycorrhiza & 0.68 & 0.64 & 50.2 & 46.1 \\
\hline & $\begin{array}{l}\text { Control (no } \\
\text { inoculum) }\end{array}$ & 0.67 & 0.59 & 39.4 & 36.4 \\
\hline \multirow{2}{*}{ Phosphoric acid (PA) } & Phosphorin & 0.66 & 0.63 & 46.8 & 41.6 \\
\hline & Mycorrhiza & 0.71 & 0.69 & 58.5 & 52.9 \\
\hline \multirow{3}{*}{$\begin{array}{l}\text { Monoammonium } \\
\text { phosphate (MAP) }\end{array}$} & $\begin{array}{l}\text { Control (no } \\
\text { inoculum) }\end{array}$ & 0.68 & 0.63 & 41.2 & 38.2 \\
\hline & Phosphorin & 0.69 & 0.65 & 49.0 & 43.7 \\
\hline & Mycorrhiza & 0.74 & 0.72 & 61.4 & 58.4 \\
\hline L.S.D. at 0.05 & & 0.07 & 0.05 & 2.9 & 1.7 \\
\hline
\end{tabular}

* Means comparison between treatments was performed with the least significant difference (LSD) test $(p=0.05)$.

\section{Discussion}

Different sources of phosphorus are being used in crop production, mainly superphosphates and rock phosphate. However, additional phosphorus fertilizers have recently become available, such as phosphoric acid, monoammonium phosphate (MAP), monopotassium phosphate (MPK) and urea phosphate (UP), which can be used to manage $P$ fertilization, especially in the cultivation of short growth cycle plants, such as vegetables. These P sources are popular due to their high phosphorus content and excellent physical properties $[37,38]$. Single and triple superphosphate precipitate when used for fertigation, thus blocking the emitters; therefore, it is necessary to utilize water soluble phosphorus sources, such as MAP and phosphoric acid to increase nutrient use efficiency and reduce production cost. Furthermore, the MAP fertilizer is composed of two fundamental components, $\mathrm{NH}_{4}+$ and $\mathrm{H}_{2} \mathrm{PO}_{4}-$, which are essential for proper plant development [39]. 
On the other hand, biofertilizers may play an essential role in enhancing crop productivity and maintaining soil fertility in the long term, while reducing the environmental burden associated with fertilizer production and nutrients leaching to groundwater deposits. In addition, the microorganisms usually included in the biofertilizers may interact with the plants and boost their immunity, growth and development, and consequently increase the crop production [40-42].

In this study, the application of MAP and phosphoric acid as an alternative source of phosphorus enhanced the vegetative growth parameters, i.e., the number of leaves/plant, leaf area, and fresh and dry weight of leaves as compared to the other phosphorus sources tested. These findings could be attributed to the high solubility and availability of phosphorus in both fertilizers, especially MAP fertilizer, which recorded the highest values of the aforementioned parameters that could be linked to its high phosphorus content $(61 \%$ as $\left.\mathrm{P}_{2} \mathrm{O}_{5}\right)$, high water solubility $\left(365 \mathrm{~g} \mathrm{~L}^{-1}\right.$ at $20^{\circ} \mathrm{C}$ ) and $\mathrm{pH}$ value (4.0 to 4.5$)$. The $\mathrm{pH}$ of the solution surrounding its particles is moderately acidic, making MAP a preferable fertilizer in neutral and alkaline soils. Moreover, MAP contains about $12 \%$ of nitrogen in ammonium $\left(\mathrm{NH}_{4}{ }^{+}\right)$form, which is less prone to leaching and is also considered as a slower release form of nitrogen, compared to nitrate form. Additionally, the decrease of $\mathrm{pH}$ in the root zone by using ammonium nitrogen may increase the degeneration of calcium-phosphorus precipitated compounds and thus enhanced the phosphorus availability and plant uptake $[39,43]$. Moreover, the observed results could be attributed to the pivotal role of phosphorus in cell division [44], as well as to its use as a structural element in macromolecular structures (e.g., DNA and RNA), in phospholipids and in cell membranes. Moreover, phosphates are included in energy-rich ions [adenosine monophosphate (AMP), adenosine triphosphate (ATP) and adenosine diphosphate (ADP)], which are related to all energy metabolism processes of cells, i.e., photophosphorylation [10].

Concerning the effect of the biofertilization, the application with mycorrhiza significantly enhanced most of the vegetative attributes, i.e., fresh and dry weights of leaves/plant as compared to phosphorin and the control treatment. These results could be attributed to the role of arbuscular mycorrhizal fungi (AMF) in improving the soil structure [45], enhancing the water absorption [46], increasing the absorption and acquisition of nutrient elements from the soil by augmenting the root area and penetration of the growing media [47-49], as well as the activation and excretion of various enzymes from plant roots and/or mycorrhizal hyphae, and the increased concentrations of endogenous hormones, i.e., gibberellins and auxins, which promote plant growth [50]. According to Yildirim et al. [51], the application of plant growth promoting rhizobacteria and manure significantly increased the vegetative growth of broccoli plants and attributed this increase to the improved uptake of macro and micronutrients from plants. However, the interaction of plants and inoculants are highly complex and difficult to interpret; therefore, the involvement of mycorrhizal inoculants in phosphorus acquisition from plants and the corresponding mechanisms need further studies [25].

The results observed for the single factors (e.g., phosphorus source and biofertilizers) were also depicted in their combinatorial effect where the best combination was the application of MAP $\times$ mycorrhiza treatment. Similar to our study, Abd-Alrahman et al. [52] suggested that the combined application of mineral and biofertilizers that contained nitrogen fixing and phosphorus solubilizing microorganisms significantly increased the vegetative parameters of broccoli plants, while Abou El-Magd et al. [53] suggested that biofertilizers could substitute mineral fertilizers resulting in increased plant growth and reduced production costs. Moreover, the combination of MAP and mycorrhiza inoculation was beneficial to plant growth parameters of snap bean, suggesting a synergistic effect on nutrient use efficiency that improves plant development [43].

Regarding the yield and quality parameters, the MAP and PA treatments recorded significantly higher values than the rest of phosphorus sources for the tested parameters, i.e., head weight, total yield of heads, and the physical and chemical quality attributes of the head, i.e., head diameter, head length, and total carbohydrate, ascorbic acid and TSS 
content. This could be explained by the high phosphorus content and water solubility of MAP and PA fertilizers. Hence, phosphorus enhances the number and mass of roots [43,44], the formation of lateral roots and root/shoot ratio of plants. Consequently, the uptake of nutrients from soil increased, leading to higher nutrient content, plant growth, total chlorophyll, total carbohydrates and carbon assimilation. According to Fihlo et al. [8], phosphorus availability regulated through the application of different doses of $\mathrm{P}_{2} \mathrm{O}_{5}\left(0-320 \mathrm{~kg} \mathrm{ha}^{-1}\right)$ is essential for broccoli productivity since it may affect head weight and diameter. Moreover, Ouda et al. [54] suggested that the combined application of manure and inorganic fertilizers was beneficial to all the tested yield parameters in broccoli crops, while increasing soil organic matter content at the same time. In the same context, Tanwar et al. [22] suggested that supplementing superphosphate fertilizers with AMF inoculation significantly improved the yield parameters of broccoli.

On the contrary, the MAP treatment showed significantly lower values of total phenols, which could probably be attributed to the fact that plants grew under optimal nutrient status without suffering from any abiotic stress from nutrient deficiency. Such an argument can be justified by the yield parameters and nutrient status of plants, as indicated in Tables 4 and 5, where treatments RP and SP resulted to lower growth and macronutrient content. There were also substantial increases in $\mathrm{N}, \mathrm{P}$, and $\mathrm{K}$ percentages in plant leaves as well as total carbohydrates following MAP and/or PA treatments, which could result in enhanced root development and formation, nutrient uptake, as well as in increased vegetative growth parameters, photosynthesis, and carbon assimilation. The availability of phosphorus is associated with carbohydrates metabolism and several studies have reported that increasing phosphorus rates results in variable effects on sugars content related to a source/sink balance between roots and aerial tissues [14].

The opposite trend was observed for total phenol content detected in broccoli heads, which decreased considerably after the inoculation with mycorrhiza. This result is in contrast with previous reports where the total phenolic compound contents were not significantly affected by the arbuscular mycorrhizal fungi (AMF) inoculation as compared with non-inoculated basil plants [55], whilst the total phenol contents in mycorrhizal inoculated lettuce plants significantly increased as compared with the non-inoculated plants [56]. It is well evidenced that the application of AMF is usually associated with the alleviation of abiotic stressor effects on plant growth, which could also affect the induction of plant secondary metabolism and the biosynthesis of stress protectant compounds, such as polyphenols $[20,23,24,46]$. However, the effect of mycorrhizal fungi on secondary metabolites content varies significantly, depending on the crop [57]. Therefore, the total phenols and the antioxidant activity seem to be correlated [58] or not correlated depending on the antioxidant activity assay [59]. The effect of AMF inoculation on the antioxidant activity also differs depending on the crop, the obtained results revealed that AMF significantly increased the antioxidant activity as compared with the other treatments, as well as on onion plants, while it had no significant effect on garlic plants [60]. The enhancement in total phenolic contents and antioxidant activity could be explained that the plant considered the mycorrhizal inoculation as an invasion or stress by the endomycorrhiza fungi, thus the plants begin to synthesize secondary compounds in the early stages of colonization, such as polyphenols; flavonoids and isoflavones [61]. Notably, the ascorbic acid content in broccoli heads was significantly increased by the AMF treatment, which was reflected in the antioxidant activity.

Furthermore, the AMF treatment enhanced the mineral content in the treated plants as compared to phorpsherine and non-inoculated plants. These findings can be attributed to the AMF merits, since AMF hyphae are thinner than roots, which make it easier to extend to soil particles and penetrate in soil pore spaces and cracks, thus allowing the plants to better absorb the nutrients through the fungal hyphae and transfer them to the root cortex through the arbuscules [23]. Furthermore, Bücking [49] highlighted the beneficial effects of mycorrhiza symbionts on nutrient uptake and transportation within plant tissues. 


\section{Conclusions}

The substitution of mineral fertilizers with organic fertilizers and biofertilizers is a promising cultivation practice towards sustainable agriculture without compromising plant growth and crop yield. The results of this study showed that rock phosphate was the most effective source of phosphorus, followed by calcium superphosphate and phosphoric acid, especially when combined with the inoculation of mycorrhiza. Therefore, the use of biofertilizers and proper fertilizer sources is a viable cultivation practice since it may increase phosphorus use efficiency as indicated by higher crop productivity and quality. In conclusion, the results of our study provide useful information to improve broccoli yield parameters and maximize utilization efficiency of $P$ fertilizer sources, while the substitution of inorganic fertilizers with biofertilizers could be useful towards the alleviation of negative impacts on the environment and the adoption of eco-friendly cultivation practices.

Author Contributions: Conceptualization, M.H.M.M.; formal analysis, R.S.M.E. and H.S.E.-D.; investigation, R.M.Y.Z.; methodology and supervision, R.S., A.A.M.A.-M., M.A. and K.A.I.; writingoriginal draft preparation, M.H.M.M. and S.A.P.; writing, review and editing, M.H.M.M. and S.A.P. All authors have read and agreed to the published version of the manuscript.

Funding: This research received no external funding.

Data Availability Statement: Not applicable.

Acknowledgments: The authors would like to thank Horticulture and Botany Departments, Faculty of Agriculture, Benha University, Egypt. Taif University Researchers Supporting Project Number (TURSP-2020/117), Taif University, Taif, Saudi Arabia. The authors also thank Prince Sattam Bin Abdulaziz University, Al-Kharj for their scientific contributions.

Conflicts of Interest: The authors declare no conflict of interest.

\section{References}

1. Singh, J.; Upadhyay, A.K.; Bahadur, A.; Singh, K.P. Dietary antioxidant and minerals in Crucifers. J. Veg. Crop Prod. 2004, 10, 33-41. [CrossRef]

2. Decoteau, D.R. Vegetable Crops; Upper Rever Company: Upper Saddle River, NJ, USA, 2000; p. 496. Available online: https:/ / www.amazon.com/Vegetable-Crops-Dennis-R-Decoteau/dp/0139569960 (accessed on 20 September 2021).

3. American Dietetics Association. Handbook of Clinical Dietetics; Yale University Press: New Haven, CT, USA, 1992 ; p. 604. Available online: https:/ /yalebooks.yale.edu/book/9780300052183/handbook-clinical-dietetics (accessed on 20 September 2021).

4. Podsedek, A. Natural antioxidants and antioxidant capacity of Brassica vegetables: A review. LWT-Food Sci. Technol. 2007, 40, 1-11. [CrossRef]

5. Petropoulos, S.A.; Di Gioia, F.; Ntatsi, G. Vegetable organosulfur compounds and their health promoting effects. Curr. Pharm. Des. 2017, 23, 2695-2696. [CrossRef] [PubMed]

6. Keck, A.S. Cruciferous vegetables: Cancer protective mechanisms of glucosinolate hydrolysis products and selenium. Integr. Cancer Ther. 2004, 3, 5-12. [CrossRef] [PubMed]

7. Rodriguez-Casado, A. The health potential of fruits and vegetables phytochemicals: Notable examples. Crit. Rev. Food Sci. Nutr. 2016, 56, 1097-1107. [CrossRef]

8. Filho, A.B.C.; da Silva, A.L.P.; Mendoza-Cortez, J.W.; Barbosa, J.C. Cauliflower and broccoli productivity as influenced by phosphorus fertilizer doses in a P-rich soil. Aust. J. Crop Sci. 2015, 9, 709-712.

9. Islam, M.H.; Shaheb, M.R.; Rahman, S.; Ahmed, B.; Islam, A.T.; Sarker, P.C. Curd yield and profitability of broccoli as affected by phosphorus and potassium. Int. J. Sustain. Crop Prod. 2010, 5, 1-7. Available online: https://www.researchgate.net/profile/Md-RayhanShaheb/publication/317139477_Curd_yield_and_profitability_of_broccoli_as_affected_by_phosphorus_and_potassium/ links/59271661a6fdcc444350763c/Curd-yield-and-profitability-of-broccoli-as-affected-by-phosphorus-and-potassium.pdf (accessed on 20 September 2021).

10. Taiz, L.; Zeiger, E. Plant Physiology; Sinauer Associates Inc.: Washington, DC, USA, 2010; p. 690. Available online: http:/ / exa.unne. edu.ar/biologia / fisiologia.vegetal/PlantPhysiologyTaiz2002.pdf (accessed on 20 September 2021).

11. Zhu, Q.; Ozores-Hampton, M.; Li, Y.; Morgan, K. Phosphorus application rates affected phosphorus partitioning and use efficiency in tomato production. Agronomy J. 2018, 110, 2050-2058. [CrossRef]

12. Emmanuel, O.C.; Akintola, O.A.; Tetteh, F.M.; Babalola, O.O. Combined application of inoculant, phosphorus and potassium enhances cowpea yield in savanna soils. Agronomy 2021, 11, 15. [CrossRef]

13. Lambers, H.; Shane, M.W.; Cramer, M.D.; Pearse, S.J.; Veneklaas, E.J. Root structure and functioning for efficient acquisition of phosphorus: Matching morphological and physiological traits. Ann. Bot. 2006, 98, 693-713. [CrossRef] 
14. Garcia-Caparros, P.; Lao, M.T.; Preciado-Rangel, P.; Sanchez, E. Phosphorus and Carbohydrate Metabolism in Green Bean Plants Subjected to Increasing Phosphorus Concentration in the Nutrient Solution. Agronomy 2021, 11, 245. [CrossRef]

15. Yang, X.J.; Finnegan, P.M. Regulation of phosphate starvation responses in higher plants. Ann. Bot. 2010, 105, 513-526. [CrossRef]

16. Markovic, S.; Cerekovic, N.; Todorovic, V.; Kljajic, N.; Mihajlovic, D. The content of NPK nutrients in vegetative organs of cauliflower (Brassica oleracea var. botrytis L.) grown in soilless culture technique. Agroznanje 2012, 13, 633-644. [CrossRef]

17. Sharma, A.; Rawat, U.S.; Yadav, B.K. Influence of phosphorus levels and phosphorus solubilizing fungi on yield and nutrient uptake by wheat under sub-humid region of Rajasthan, Indian. ISRN Agron. J. 2012, 234656, 1-9. [CrossRef]

18. Hansen, J.C.; Cade-Menun, B.J.; Strawn, D.G. Phosphorus speciation in manure-amended alkaline soils. J. Environ. Qual. 2004, 33, 1521-1527. [CrossRef]

19. Plaxton, W.C.; Tran, H.T. Metabolic adaptations of phosphate-starved plants. Plant Physiol. 2011, 156, 1006-1015. [CrossRef]

20. Pang, J.; Ryan, M.H.; Lambers, H.; Siddique, K.H. Phosphorus acquisition and utilisation in crop legumes under global change. Curr. Opin. Plant Biol. 2018, 45, 248-254. [CrossRef]

21. Pandey, V.P.; Mishra, R.S. Integated nutrient management in Coriander (Coriander sativum L.). Plant Arch. $2013,13,807-808$.

22. Tanwar, A.; Aggrwal, A.; Parkash, V. Effect of bioinoculants and superphosphate fertilizer on the growth and yield of broccoli (Brassica oleracea. L. var italic Plenck). N. Z. J. Crop Hortic. 2014, 42, 288-302. [CrossRef]

23. Giovannini, L.; Palla, M.; Agnolucci, M.; Avio, L.; Sbrana, C.; Turrini, A.; Giovannetti, M. Arbuscular mycorrhizal fungi and associated microbiota as plant biostimulants: Research Strategies for the Selection of the Best Performing Inocula. Agronomy 2020, 10, 106. [CrossRef]

24. Sbrana, C.; Avio, L.; Giovannetti, M. Beneficial mycorrhizal symbionts affecting the production of health-promoting phytochemicals. Electrophoresis 2014, 35, 1535-1546. [CrossRef]

25. Richardson, A.E.; Simpson, R.J. Soil microorganisms mediating phosphorus availability. Plant Physiol. 2011, 156, 989-996. [CrossRef]

26. Raja, A.R.; Shah, K.H.; Aslam, M.; Memon, M.Y. Response of phosphobacterial and mycorrhizal inoculation in wheat. Asian J. Plant Sci. 2002, 1, 322-323. [CrossRef]

27. Jackson, M.L. Soil Chemical Analysis; Printice-Hall of India. Privat Limited: New Delhi, India, 1973. Available online: https:/ / www.scirp.org/(S(351jmbntvnsjt1aadkposzje))/reference/ReferencesPapers.aspx?ReferenceID=1453838 (accessed on 20 September 2021).

28. Black, C.A.; Evans, D.O.; Ensminger, L.E.; White, J.L.; Clark, F.E.; Dinauer, R.C. Methods of Soil Analysis. Part 2. Chemical and Microbiological Properties, 2nd ed.; Page, A.L., Ed.; Soil Science Society of America, Inc.: Madison, WI, USA, 1982.

29. Herbert, D.; Phipps, P.J.; Strange, R.E. Determination of total carbohydrates. Methods Microbiol. 1971, 5, $290-344$.

30. Pregl, E. Quantitative Organic Micro Analysis, 4th ed.; J. \& A. Churchill: London, UK, 1945.

31. John, M.K. Colorimetric determination of phosphorus in soil and plant material with ascorbic acid. Soil Sci. 1970, 109, 214-220. Available online: https://journals.lww.com/soilsci/Citation/1970/04000/COLORIMETRIC_DETERMINATION_OF_ PHOSPHORUS_IN_SOIL.2.aspx (accessed on 20 September 2021). [CrossRef]

32. Brown, J.; Lilleland, O. Rapid determination of potassium and sodium in plant material and soil extracts by flame photometric. Proc. Amer. Soc. Hort. Sci. 1946, 48, 341-346.

33. Lu, J.; Zhao, H.; Chen, J.; Fan, W.; Dong, J.; Kong, W.; Sun, J.; Cao, Y.; Cai, G. Evaluation of phenolic compounds and antioxidant activity during malting. J. Agric. Food Chem. 2007, 55, 10994-11001. [CrossRef] [PubMed]

34. AOAC. Official Methods of Analysis. Association of Official Analytical Chemists, 15th ed.; AOAC: Washington, DC, USA, 1990. Available online: https:/ /law.resource.org/pub/us/cfr/ibr/002/aoac.methods.1.1990.pdf (accessed on 20 September 2021).

35. Schinner, F.; Oehlinger, R.; Kandeler, E.; Margesin, R. Methods in Soil Biology. Springer Lab Manuals, Part I; Springer: Cham, Switzerland, 1997; pp. 213-241. Available online: https://www.springer.com/gp/book/9783642646331 (accessed on 20 September 2021).

36. Snedecor, G.W.; Cocharn, W.G. Statistical Methods, 8th ed.; Iowa State Univ. Press: Ames, IW, USA, 1991. Available online: https:/ / www.wiley.com/en-us/Statistical+Methods\%2C+8th+Edition-p-9780813815619 (accessed on 20 September 2021).

37. Chien, S.H.; Prochnow, L.I.; Cantarella, H. Recent developments of fertilizer production and use to improve nutrient efficiency and minimize environmental impacts. Adv. Agron. 2009, 102, 267-322. [CrossRef]

38. Rosen, C.J.; Kelling, A.K.; Stark, J.C.; Porter, G.A. Optimizing phosphorus fertilizer management in potato production. Am. J. Potato Res. 2014, 91, 145-160. [CrossRef]

39. Chien, S.H.; Prochnow, L.I.; Tu, S.; Snyder, C.S. Agronomic and environmental aspects of phosphate fertilizers varying in source and solubility: An update review. Nutr. Cycl. Agroecosyst. 2011, 89, 229-255. [CrossRef]

40. Reddy, G.C.; Goyal, R.K.; Puranik, S.; Waghmar, V.; Vikram, K.V.; Sruthy, K.S. Biofertilizers Toward Sustainable Agricultural Development. In Plant Microbe Symbiosis; Varma, A., Tripathi, S., Prasad, R., Eds.; Springer: Cham, Switzerland, 2020; pp. 115-128.

41. Nosheen, S.; Ajmal, I.; Song, Y. Microbes as Biofertilizers, a Potential approach for sustainable crop production. Sustainability 2021, 13, 1868. [CrossRef]

42. Petrovic, B.; Sękara, A.; Pokluda, R. Biofertilizers enhance quality of onion. Agronomy 2020, 10, 1937. [CrossRef]

43. Youssef, S.M.; Riad, G.S.; Abd Elhady, S.A. Effect of phosphorus sources and arbuscular mycorrhizal inoculation on growth and productivity of snap bean (Phaseolus vulgaris L.). Gesunde Pflanz. 2017, 69, 139-148. Available online: https://agris.fao.org/agrissearch/search.do?recordID=US201700264036 (accessed on 20 September 2021). [CrossRef] 
44. Hawkesford, M.; Horst, W.; Kichey, T.; Lambers, H.; Schjoerring, J.; Møller, I.S.; White, P. Functions of Macronutrients. In Marschner's Mineral Nutrition of Higher Plants, 3rd ed.; Marschner, P., Ed.; Academic Press, Inc.: London, UK, 2012 ; pp. 178-189. [CrossRef]

45. Miller, R.M.; Jastrow, J.D. Mycorrhizal fungi influence soil structure. In Arbuscular Mycorrhizas Physiology and Function; Kapulnik, Y., Douds, D.D., Jr., Eds.; Kluwer: Dordrecht, The Netherlands, 2000; pp. 3-18. Available online: https://link.springer.com/ content/pdf/10.1007\%2F978-94-017-0776-3.pdf (accessed on 20 September 2021).

46. Augé, R.M. Water relations, drought and vesicular-arbuscular mycorrhizal symbiosis. Mycorrhiza 2003, 11, 3-42. [CrossRef]

47. Li, H.; Smith, S.E.; Holloway, R.E.; Zhu, Y.; Smith, F.A. Arbuscular mycorrhizal fungi contribute to phosphorus uptake by wheat grown in a phosphorus-fixing soil even in the absence of positive growth responses. New Phytol. 2006, 172, 536-543. [CrossRef]

48. Abdel Motaleb, N.A.; Abd Elhady, S.A.; Ghoname, A.A. AMF and Bacillus megaterium neutralize the harmful effects of salt stress on bean plants. Gesunde Pflanz. 2020, 72, 29-39. [CrossRef]

49. Bücking, H.; Liepold, E.; Ambilwade, P. The role of the mycorrhizal symbiosis in nutrient uptake of plants and the regulatorymechanisms underlying these transport processes. Plant Sci. 2012, 4, 108-132. [CrossRef]

50. Brahmaprakash, G.; Sahu, P.K. Biofertilizers for sustainability. J. Indian Inst. Sci. 2012, 92, 37-62.

51. Yildirim, E.; Karlidag, H.; Turan, M.; Dursun, A.; Goktepe, F. Growth, Nutrient Uptake, and Yield Promotion of Broccoli by Plant Growth Promoting Rhizobacteria. Hort Sci. 2011, 46, 932-936. [CrossRef]

52. Abd-Alrahman, H.A.; Zaki, M.F.; El-Behairy, U.A.; Abou Hadid, A.F.; Abou El-Magd, M.M. Growing broccoli plants in the newly reclaimed soils of Egypt, as affected by different fertilizer sources. Int. J. ChemTech Res. 2016, 9, 1-11.

53. Abou El-Magd, M.M.; Zaki, M.F.; Abo Sedera, S.A. Effect of bio-nitrogen as a partial alternative to mineral-nitrogen fertilizer on growth, yield and head quality of broccoli (Brassica oleracea L. var. italica). World Appl. Sci. J. 2014, 31, 681-691. [CrossRef]

54. Ouda, B.A.; Mahadeen, A.Y. Effect of fertilizers on growth, yield, yield components, quality and certain nutrient contents in broccoli (Brassica oleracea). Int. J. Agric. Biol. 2008, 10, 627-632.

55. Hazzoumi, Z.; Moustakime, Y.; Elharchli, E.; Joutei, K.A. Effect of arbuscular mycorrhizal fungi (AMF) and water stress on growth, phenolic compounds, glandular hairs, and yield of essential oil in basil (Ocimum gratissimum L). Chem. Biol. Technol. Agric. 2015, 2, 10. [CrossRef]

56. Avio, L.; Sbrana, C.; Giovannetti, M.; Frassinetti, S. Arbuscular mycorrhizal fungi affect total phenolics content and antioxidant activity in leaves of oak leaf lettuce varieties. Sci. Hortic. 2017, 224, 265-271. [CrossRef]

57. Agnolucci, M.; Avio, L.; Palla, M.; Sbrana, C.; Turrini, A.; Giovannetti, M. Health-promoting properties of plant products: The role of mycorrhizal fungi and associated bacteria. Agronomy 2020, 10, 1864. [CrossRef]

58. Viacava, G.E.; Gonzalez-Aguilar, G.; Roura, S.I. Determination of phytochemicals and antioxidant activity in butterhead lettuce related to leaf age and position. J. Food Biochem. 2014, 38, 352-362. [CrossRef]

59. Golubkina, N.; Amagova, Z.; Matsadze, V.; Zamana, S.; Tallarita, A.; Caruso, G. Effects of Arbuscular Mycorrhizal Fungi on Yield, Biochemical Characteristics, and Elemental Composition of Garlic and Onion under Selenium Supply. Plants 2020, 9, 84. [CrossRef] [PubMed]

60. Giovannetti, M.; Avio, L. Biotechnology of arbuscular mycorrhizas.Mycorrhizas. In Applied Mycology and Biotechnology, Vol. 2. Agriculture and Food Production; Khachatourians, G.G., Arora, D.K., Eds.; Elsevier: Amsterdam, The Netherlands, 2002; pp. 275-310. Available online: https:/ / www.elsevier.com/books/agriculture-and-food-production/khachatourians/978-0-44 4-51030-3 (accessed on 20 September 2021).

61. Bago, B.; Azcón-Aguilar, C.; Goulet, A.; Piché, Y. Branched absorbing structures (BAS): A feature of the extraradical mycelium of symbiotic arbuscular mycorrhizal fungi. New Phytol. 1998, 139, 375-388. [CrossRef] 